\title{
震災の記憶·記録とアーカイブズ
}

\section{Memory, Record, and Archives of the Disaster}

\author{
梶川裕矢 ${ }^{1 *}$ \\ Yuya KAJIKAWA ${ }^{1 *}$
}

1 東京工業大学

Tokyo Institute of Technology

干 108-0023 東京都港区芝浦3-3-6

E-mail: kajikawa@mot.titech.ac.jp

現在、震災の記憶を記録し、アーカイブズとして後世に伝えるための様々なプロジェクトが産官学 で実施されている。本フォーラムでは、産官学で様々に実施されている震災のアーカイブズプロジェ クトの現状と課題を共有し、アーカイブズとは何か、どのようにあるべきか、どのように活用できるとい ったことについて、第一線で活躍されている講師の方々および参加者の方々と議論することを目的と している。

まずは、現在、各所で取り組まれている震災アーカイブズプロジェクトについて現状を共有しよう。 河合論文では、国立国会図書館が実施している東日本大震災アーカイブ構築プロジェクトの概要の 解説を行っている。アーカイブの対象は、震災やその被害だけでなく,被災以前・以降の地域の記録、 過去に発生した災害に関する記録なじを含んでいる。さらには、国会東京電力福島原子力発電所 事故調査委員会の調査資料も保管対象に含まれており、後世の貴重な資料となるであろう。宮本論 文で紹介されている「NHK東日本大震災アーカイブス」では、被災者の証言だけでなく、行動経路 や津波浸水域が地図上に表示され、震災当時の緒言者が置かれていた状況をよりリアルに伝える 工夫がなされている。また、中嶋らの論文では、日本原子力研究開発機構図書館が実施している福 島第一原子力発電所事故の文献情報の収集に関して紹介がなされている。

本フォーラムでは、アーカイブズ、歴史学、災害・防災学など多様な分野の専門家から多岐に渡る 論点が提起される。

その中の一つはアーカイブズの連携である。震災に関する記憶や記録は、単独の機関で収集し、 アーカイブ化することが可能というわけではもちろんない。例えば、国会図書館で進められているプ ロジェクトでは、インターネット上の情報の収集対象は主に公的機関によるものに限られているし。従 って、河合論文で述べられているように、「東日本大震災アーカイブを実現するためには, 震災の記 録等の収集及び活用における役割分担」や、「コンテンツ収集や統合検索のためのメタデータ連携, アーカイブシステム構築等での協力」が重要である。岡本論文で述べられているように、アーカイビン 
グの際の利用許諾手続きに関しては当初より関係者間で連携が取られていた。しかし、震災に関す る物的保全の在り方、アナログ情報のアーカイビングや、デジタル情報の横断検索等に関しては、ま だ具体的な解決に至っていない。

また、アーカイブ化の議論においてはしばしば、アーカイブすることが目的化しており、記録する、 アーカイブすることの意味や意義をめぐる社会学的・哲学的な問いが抜け落ちているよう思われる。 失われる記憶や記録が風化する前に、まずはアーカイブすることが必要である一方、震災を記録す ることの意義は何か、またどのような形でアーカイブするのが望ましいのかといった議論を同時に展 開する必要がある。この点に関し、松島論文では、被災者の記憶を記録するオーラルヒストリーという 手法が持つ難しさが提起されている。一点目は、時間的距離、すなわち、語る事象と語る時点が近 すぎず遠すぎないことであり、もう一点は、聞き手と語り手の心理的距離である。この被災者と記録や アーカイブとの距離に関しては、災害研究者としての自省から始まる杉本論文において記念碑やメ ッセージフラワーを例にとり、存分に語られている。

最後に、アーカイブおよびアーカイブ化の持つ意義である。北原論文では、災害史や過去の資料 が、その時代や人々を鮮明に浮かび上がらせる様が描かれている。奥村論文では、社会が変化し、 人口の流動性が高い現代では記憶の継承が困難となっている一方で、私」の記憶を「公共」の記憶 へと意識的に展開していく動きが、市民レベルで広範に展開しはじめていることを指摘している。奥 村論文で述べられている、歴史資料ネットワークがハブとなり各地で歴史・文化資料を保全する動き が広がっている様は注目に值しよう。北原論文でも指摘されているように、震災での相互扶助の思い は変わらない。震災時の相互扶助が同時代を生き、震災を経験したものを横に繋げるものだとする なら、地域の歴史文化はそれを縦に繋げるものといえるだろう。震災の記憶・記録のアーカイブ化を 地域の歴史と文化を繋ぐ、もしくは繋ぎ直す契機となすといら考え方も重要なのではないだろうか。

フォーラムでは第一線の専門家から、様々な情報や論点が提起されるだろう。そこから何を汲みと り行動に移すかは我々一人一人に委ねられている。忘れてならないのは、震災復興を進めると同時 に震災の記憶を後世へと残すことが、現在を生きる我々の責務であるということだ。本フォーラムの開 催を通じて、震災のアーカイブズに隽わる方々にとってだけでなく、311以降の現在を生きる我々自 身、さらには将来の世代のために何らかの貢献ができれば幸いである。 